\title{
Viðhorf leikskólakennara og leiðbeinenda til upphafs leikskólagöngu barna
}

\author{
Hrönn Pálmadóttir \\ Abstract Um höfund $\backslash$ About the author $>$ Heimildir
}

Greinin er byggð á rannsókn sem ætlað er að varpa ljósi á viðhorf og reynslu leikskólakennara og leiðbeinenda í einum leikskóla í Reykjavík af samstarfi við foreldra- og barnahóp með fjölbreyttan bakgrunn og menningu í upphafi leikskólagöngu. Tímamótin eru kölluð aðlögun og er par vísað til inntöku nýrra barna í leikskóla. Hugmyndafræðilegur grunnur rannsóknarinnar er að mestu sóttur í smiðju fræðimanna sem hafa rannsakað pau páttaskil sem verða pegar börn hefja grunnskólagöngu. Margir sömu pættir koma einnig við sögu við upphaf leikskólagöngu. Litið er á börn sem mikils megnug og skapandi og að námsumhverfi og námskrá skuli byggjast á áhuga og aðstæðum barna og taka tillit til pess að pau eru ólík (Educational Transitions and Change Research group, 2011).

Gagna var aflað með eigindlegum rannsóknaraðferðum; einstaklingsviðtölum, rýnihópaviðtölum og vettvangsathugunumá premur deildumíleikskólanum. Greining gagna fór fram með pemagreiningu, en hún er sveigjanleg aðferð sem notuð er til að skipuleggja og greina gögn (Braun og Clarke, 2013). Niðurstöður rannsóknarinnar sýndu að leikskólakennarar lýstu hlutverki sínu í aðlögunarferlinu sem tvípættu. Annars vegar að koma á og viðhalda tilfinningalegum tengslum við foreldra og börn. Hins vegar að hafa yfirsýn, ýta undir samstarf innan deilda og miðla pekkingu til samstarfsfólksins. Leiðbeinendur ræddu um virka pátttöku í aðlögunarferlinu og í samskiptum og tengslum við foreldra barnanna eftir að formlegri aðlögun lauk. Pátttökuaðlögun var talin reynast vel sem sameiginlegt námsferli foreldra, barna og leikskólastarfsfólks. Fram komu vísbendingar um að foreldrar af erlendum uppruna ættu frekar í erfiðleikum með pátttöku og að börn af erlendum uppruna upplifðu í mörgum tilvikum erfiðari aðlögun en börn íslenskra foreldra. Rannsóknin sýnir að pað er fagleg áskorun að próa starfshætti sem stuðla að pví að skapa samfellu í lífi barna með fjölbreyttan bakgrunn og menningu frá upphafi leikskólagöngu.

Efnisorð: Upphaf leikskólagöngu, aðlögun, fjölbreyttur bakgrunnur og menning, samfella, starfshættir

\section{Inngangur}

Miklar breytingar hafa átt sér stað í leikskólum hér á landi á undanförnum árum par sem börn byrja sífellt yngri í leikskóla og samsetning barnahópsins hefur breyst. Árið 2018 voru 48\% barna yngri en tveggja ára í leikskólum og um 13\% allra barna voru af erlendum uppruna (Hagstofa Íslands, e.d.). Dessar breytingar eru í samræmi við pað sem gerst hefur í öðrum vestrænum ríkjum. Í skýrslu OECD (2017) er bent á að samstarf við foreldra sé mikilvægur gæðapáttur í leikskólastarfi og helstu áskoranir felist í að mæta aukinni fjölbreytni innan foreldrahópsins. Í aðalnámskrá segir að fyrstu skref barnsins í leikskólanum skuli byggjast á gagnkvæmri miðlun upplýsinga milli foreldra og leikskóla um starfshætti, hugmyndafræði og námskrá leikskólans 
auk aðstæðna og reynslu barnsins heima fyrir (Mennta- og menningarmálaráðuneytið, 2011). Mikilvægur grunnur er pví lagður að samstarfi foreldra og starfsfólks leikskóla pegar fjölbreyttur hópur barna hefur leikskólagöngu. Tímamótin eru kölluð aðlögun og er par vísað til inntöku nýrra barna í leikskóla.

Lög hér á landi kveða ekki á um hvenær börn eigi rétt á að hefja leikskólagöngu (lög um leikskóla nr. 90/2008). Alllengi hefur verið rætt um að lengja fæðingar- og foreldraorlof úr níu mánuðum í eitt ár. Í rökstuðningi fyrir pví segir að ráđstöfunin sé mikilvæg til að ná velferðar- og menntunarlegum markmiðum samfélagsins auk pess að samræma fjölskyldu og atvinnulíf (Mennta- og menningarmálaráđuneytið, 2015; Velferðarráðuneytið, 2016). Nú hefur verið sampykkt á Alpingi að lengja fæðingar- og foreldraorlof í tólf mánuði og að pað komi til framkvæmda árin 2020-2021 (Lög um breytingu á lögum um fæðingar- og foreldraorlof, nr. 95/2000 með síðari breytingum 2019). Dað er pví ljóst að vilji yfirvalda stendur til pess að opna leikskóla fyrir börn frá eins árs aldri en mælt er með að sveitarfélög byrji í áföngum og hefji inntöku barna um 18 mánaða aldur (Mennta- og menningarmálaráðuneytið, 2015). Sum sveitarfélög bjóða nú pegar börnum leikskóladvöl frá eins árs aldri.

Mismunandi sjónarhorn og áherslur fræðimanna hafa litað umræðu um hvort og hvenær ákjósanlegt sé að börn byrji leikskólagöngu. Umræðan tengist gjarnan hlutverki foreldra í lífi barna og hvort leikskólinn sé í stakk búinn til að taka á móti ungum börnum (Kihlbom, Lidholt og Niss, 2009; Sæunn Kjartansdóttir, 2009). Gjarnan er vísað í tengslakenningar (e. attachment theories) par sem tengsl milli foreldra og barns eru í brennidepli og talið að aðskilnaður snemma á lífsleiðinni geti haft skaðleg áhrif á barnið (Belsky, 2009; Bowlby, 1969). Einnig séu möguleikar í leikskólum til að veita ungum börnum tilfinningalega einstaklingsumhyggju takmarkaðir sökum fjölda barna í hópi, ónógrar menntunar starfsfólks og starfsmannaveltu (Alvestad o.fl., 2013; Dalli, White, Rockel og Duhn, 2011; Løkken, Bjørnestad, Broekhuizen og Moser, 2018; Undheim og Drugli, 2012). Pá sé húsnæði leikskóla ekki hannað með parfir yngstu barnanna 1 huga (Bjørnestad og Pramling-Samuelsson, 2012; Jón Torfi Jónasson, 2006). Niðurstöður rannsókna hafa sýnt að leikskólastjórnendur og leikskólakennarar hafa áhyggjur af löngum dvalartíma ungra barna í leikskólum (Arna H. Jónsdóttir, Bryndís Garðarsdóttir og Jóhanna Einarsdóttir, 2013; Johansen, 2009).

Á hinn bóginn hefur yfirfærsla tengslakenninga á leikskólastarf verið gagnrýnd og pví haldið fram að of mikil áhersla sé lögð á tengsl móður og barns og áhrif aðskilnaðar á kvíða barna. Hæfni barna til að eiga í fjölbreyttum tengslum sé par með útilokuð og ekki sé gert ráð fyrir áhrifum umhverfis á proska barna (Clare, 2012; Nutbrown og Page, 2008). Enn fremur purfi að byggja á langtímarannsóknum pegar áhrif leikskóladvalar á börn eru metin. Norrænar rannsóknir á leikskólagöngu eins til fjögurra ára barna sýndu fram á jákvæð áhrif á félagsfærni barna við átta ára aldur (Bohlin, Hagekull og Anderson, 2005). Niðurstöður rannsóknar sem fór fram í Bandaríkjunum (NICHD Early Child Care Research Network, 2003, 2006) og EPPErannsóknarinnar í Bretlandi (Sylva, Melhuish, Sammons, Siraj-Blatchford og Taggart, 2011) sýna að pættir eins og fjölskylduaðstæður barna og gæði leikskóla, sem felast m.a. í menntun kennara, eru einnig áhrifaríkir í proska og námi barna.

Vellíðan barna og fjölskyldna peirra felst í mörgu öðru en að fá úthlutað plássi í leikskóla. Spyrja má hvernig leikskólakennarar upplifa pær margvíslegu áskoranir sem fólgnar eru í aðlögun ungra barna. Markmiðið með greininni er að varpa ljósi á viðhorf og reynslu leikskólakennara og leiðbeinenda í einum leikskóla í Reykjavík af samstarfi við foreldra- og barnahóp með fjölbreyttan bakgrunn og menningu í upphafi leikskólagöngu.

\section{Fræðilegur bakgrunnur}

Hugmyndafræðilegur grunnur rannsóknarinnar sem hér er kynnt er að mestu sóttur í smiðju fræðimanna sem hafa rannsakað páttaskilin sem verða pegar börn hefja grunnskólagöngu. Litið 
er á börn sem mikils megnug og skapandi og að námsumhverfi og námskrá skuli byggjast á áhuga og aðstæðum barna og taka tillit til pess að pau eru ólík (Dockett og Jóhanna Einarsdóttir, 2017; Dunlop, 2017; Educational Transitions and Change Research Group [ETC], 2011). Prátt fyrir að rannsóknirnar beinist fyrst og fremst að upphafi grunnskólagöngu má færa rök fyrir pví að margir sömu pættir komi einnig við sögu við upphaf leikskólagöngu. Aðlögun í leikskóla felur í sér að barnið er að flytjast úr einu umhverfi í annað, frá heimili eða dagforeldrum á nýjan stað, leikskólann.

\section{Aðlögun}

Aðlögun í leikskóla er tímabil breytinga í lífi barns og fjölskyldu pess. Breytingarnar einkennast af flóknu ferli par sem hugtökin umbreyting (e. transition) og aðlögun (e. adaption) eru samtvinnuð (Margetts, 2014). Breytingarnar hafa áhrifá alla sem pær snerta og skipta pví samskipti og samstarf milli fjölskyldu og leikskóla höfuðmáli. Drugli og Undheim (2011) benda á að aðlögunarferlið sé samtvinnað námsferli barna, foreldra og leikskólakennara. Aðlögun snýst ekki einungis um að verið er að venja barnið við aðskilnað við foreldra, heldur einnig að pað er að kynnast nýju umhverfi, eiga samskipti og mynda tengsl við starfsfólk og nýja félaga (Broberg, 2017; Dalli, 2002; Kristín Dýrfjörð, 2009). Ferlið byrjar heima og heldur áfram par til barnið og fjölskylda pess upplifa sig sem pátttakendur og að pau tilheyri (e. belong) nýja umhverfinu. Dví meiri breytingar sem fjölskyldan parf að takast á við í upphafi leikskólagöngu, peim mun erfiðari getur umbreytingin orðið (Margetts, 2014).

Viðurkennt er að aðlögun barna í leikskóla parfnist sérstaks skipulags. Pó mismunandi geti verið á milli leikskóla hvernig skipulagningu aðlögunar er háttað er jafnan gert ráð fyrir að hún taki tíma par sem parfir og vellíðan barnsins verði að vera í fyrirrúmi. Rannsóknir sýna að leikskólakennarar leggja áherslu á að skapa traust og styðja foreldra og börn í aðlögunarferlinu (Traum og Moran, 2016; White o.fl., 2020). Í niðurstöðum rannsóknar par sem gildi, sannfæring og merking sem foreldrar og leikskólakennarar lögðu í aðlögun barna var könnuð kom í ljós að bæði kennarar og foreldrar tóku pátt í að skapa og koma á einstaklingsbundnum leiðum til að auðvelda aðlögun. Báđir hópar upplifðu pó stundum óöryggi og voru áhyggjufullir vegna aðlögunar barnanna (Traum og Moran, 2016).

Til að koma á tengslum og styðja fjölskyldur í aðlögunarferlinu hefur verið farin sú leið í sumum leikskólum að velja lykilpersónu (e. key person) úr starfsmannahópnum til að aðstoða fjölskyldur í ferlinu. Lykilpersónan próar náin tengsl við ákveðin börn og foreldra og á pannig að öðlast góða yfirsýn yfir parfir barnanna og nám (Clare, 2012; Nutbrown, 2011). Elfer (2006, 2012) telur að breið samstaða ríki um mikilvægi pess að starf með ungum börnum byggist á tilfinningalegum tengslum og næmi (e. emotional attachment). Á hinn bóginn séu leikskólakennarar ekki sammála um hversu langt eigi að fara í skipulagningu samskipta og að ýta undir tengsl barns við ákveðinn aðila í leikskólanum. Í handbókum Reykjavíkurborgar um samstarf leikskóla við fjölskyldur og um fjölmenningu í leikskóla er lagt til að lykilpersóna úr starfsmannahópnum taki á móti og sinni barni og foreldrum meðan á aðlögun stendur (Reykjavíkurborg, 2010, 2011).

Hér á landi hafa aðallega verið farnar tvær leiðir við skipulagningu aðlögunar í leikskólum. Annars vegar er pað aðlögun sem lengist dag frá degi. Hún byggist á að barnið kemur fyrst með foreldrum sínum í stutta heimsókn og næstu daga fara foreldrar í burtu í ákveðinn tíma sem smám saman lengist. Tilgangurinn er að barnið kynnist starfsfólki og umhverfi og að traust myndist milli pess og starfsfólks. Foreldrar byrja á að dvelja með barni sínu en sækja pað síðan á ýmsum tímum og fá pannig innsýn í daglegt líf í leikskólanum. Mismunandi er hversu langan tíma pessi aðlögun tekur en miðað er við að skipuleggja hana í samstarfi við foreldra og parfir barnsins (Reykjavíkurborg, 2011). Bent hefur verið á að petta form aðlögunar byggist á hugmyndum tengslakenninga (t.d. Bowlby, 1969) par sem tilgangurinn sé fyrst og fremst að venja barnið við aðskilnað við foreldra og láta pað takast á við pann kvíða og óöryggi sem fylgir pví að yfirgefa pá (Dalli, 2002; Kristín Dýrfjörð, 2009). 
Á síðustu árum hefur pátttökuaðlögun rutt sér til rúms í leikskólum. Par er gert ráð fyrir viðveru og pátttöku foreldra með barninu í leikskólanum fyrstu prjá daga aðlögunar en á fjórða degi kveðja foreldrar börnin. Pá daga sem foreldrar eru með börnum sínum í leikskólanum taka peir fullan pátt í starfinu og eru til staðar fyrir börn sín allan tímann. Tilgangurinn er að gefa starfsfólki tækifæri til að læra af foreldrunum um venjur barnsins og hvað hentar pví best (Reykjavíkurborg, 2011). Detta form aðlögunar tengist hugmyndum bernskurannsókna par sem litið er á börn sem hæfa og getumikla einstaklinga (Dahlberg og Moss, 2005; Jóhanna Einarsdóttir, 2012; Trewarthen, 2018) sem ásamt foreldrum sínum læri í sameiningu á námsumhverfið í leikskólanum. Pannig skapi reynsla foreldra öryggi sem hafi áhrif á börnin og aðlögun peirra (Kristín Dýrfjörð, 2009).

\section{Samfella}

Samfella (e. continuity) felur í sér að byggt er á reynslu barna á fyrra skólastigi eða á heimili pegar pau hefja leikskólagöngu (Dockett og Jóhanna Einarsdóttir, 2017; Margetts, 2002). Samfella milli heimilis og leikskóla snýst um að byggja á pví sem börnin hafa pegar lært og pekkja fyrir pegar pau koma í nýjar aðstæður í leikskólanum. Pannig er gert rád fyrir hæfni barnsins til að taka pátt og hafa áhrif á umhverfi sitt. Pað hvernig staðið er að pví að skapa samfellu á milli pessara tveggja heima sem barnið tilheyrir hefur pví ekki síður áhrif á aðlögun barnsins en aðskilnaður pess við foreldra (Berns, 2007).

Menningarleg samfella (e. cultural continuity) lýsir hæfni kennara til að hlusta, skilja, virða og byggja á menningarlegum og mállegum hefðum heimila. Menningarleg samfella vísar einnig til ákvarðana sem teknar eru í skólanum og eru í samræmi við fjölmenningarlegt umhverfi barnanna sem skólann sækja (Nieto og Bode, 2010; Souto-Manning, 2013). Menning vísar ekki eingöngu til pjóðernis eða uppruna heldur tengist einnig fjölbreyttum lífsstíl fjölskyldna, fjölskylduskipan, hegðun og uppeldi (Hanna Ragnarsdóttir, 2007). Heimamenning ungra barna getur t.d. verið ólík hvað varðar svefnvenjur, uppeldisaðferðir, nánd og væntingar foreldra til sjálfstæðis barna sinna. Fjölbreyttur barnahópur kallar á að menningar- og félagslegur bakgrunnur allra barna nýtist peim á vettvangi leikskólans. Zachrisen (2017) bendir á að leikskólakennarar verði að búa yfir menningarlegu næmi og umhyggju (e. culturally sensitive care) og að öll samskipti í leikskóla fari fram í menningar- og félagslegu samhengi. Faglegt sjónarhorn snýst um að taka tillit til pess í samskiptum við fjölskyldur, sem og í skipulagi leikskólastarfs.

Sköpun samfellu í lífi ungra barna í leikskóla felur í sér ólíka fleti samskipta og tengsla milli leikskólakennara, foreldra og barna. Í rannsóknum par sem viðhorf leikskólakennara til eigin hlutverks og fagmennsku í samstarfi sínu við foreldra barna hefur verið kannað kemur fram áhersla á að byggja upp og viðhalda tengslum sem einkennast af trausti og tiltrú (Hostettler Schärer, 2018; Vuorinen, Sandberg, Sheridan og Williams, 2014). Leikskólakennararnir í rannsókn Hostettler Schärer (2018) túlkuðu faglegt hlutverk sitt í upphafi leikskólagöngu barna sem tvípætt. Annars vegar tengdist pað samskiptum við börn og foreldra og hins vegar fólst pað í skipulagspáttum, svo sem dagskipulagi og vöktum starfsfólks. Í rannsókn Brooker (2010) kom fram að prátt fyrir að skýr stefna um samstarf og tengsl við foreldra í upphafi leikskólagöngu hefði verið ákveðin, pá hefði reynst erfitt að byggja upp opinská samskipti milli peirra og leikskólakennara. Einnig eru vísbendingarí rannsóknum um að foreldrar af erlendum uppruna upplifi sig jaðarsetta (e. culturally distant) gagnvart ríkjandi menningu leikskóla (Chan og Ritchie, 2016; Hanna Ragnarsdóttir, 2008) og að tungumálið geti hindrað samskipti og pátttöku peirra í leikskólastarfinu (Anna Lilja Sævarsdóttir, Anna Elísa Hreiðarsdóttir og Hermína Gunnpórsdóttir, 2013; Arna H. Jónsdóttir og Jóhanna Einarsdóttir, 2017; Hedlin, 2017).

\section{Rannsóknarspurningar}

Rannsókninni er ætlað að veita innsýn í viðhorf og reynslu leikskólastarfsfólks í einum leikskóla í Reykjavík af upphafi leikskólagöngu og samstarfi við fjölskyldur með fjölbreyttan bakgrunn og 
menningu. Jafnframt er ætlunin að skoða hvaða augum starfsfólk lítur á samfellu í lífi barnanna. Með pví er reynt að skilja hvaða merking er lögð í pessa pætti starfsins og bæta pannig við pá pekkingu sem fyrir er.

Eftirfarandi rannsóknarspurningum verður svarað í pessari grein:

- Hvaða augum líta leikskólakennarar og leiðbeinendur á aðlögun barna með fjölbreyttan bakgrunn og menningu?

- Hvaða áhersla er lögð á að skapa samfellu í lífi barnanna í leikskólanum?

\section{Rannsóknin}

Í rannsóknina var valinn leikskóli par sem alllöng reynsla er af samstarfi við fjölskyldur með fjölbreyttan bakgrunn og menningu. Börn yngri en tveggja ára hófu leikskólagöngu sína á premur deildum haustið sem rannsóknin hófst. Leikskólakennarar, allt konur, voru í stöðum deildarstjóra. Tveir deildarstjóranna höfðu reynslu af starfi með ungum börnum en einn peirra hafði starfað meirihluta starfsævinnar með eldri börnum. Auk deildarstjóranna störfuðu tveir til fjórir aðrir starfsmenn á deildunum. Deir höfðu mislanga reynslu af að vinna með svo ungum börnum, allt frá mörgum árum til pess að petta var fyrsti veturinn með yngstu börnunum. Á tveimur deildum voru starfsmenn af erlendum uppruna og hafði annar peirra starfað í leikskóla í nokkur ár. Leikskólastjórinn var með margra ára reynslu sem stjórnandi í leikskóla.

Degar ný börn byrja í leikskólanum er foreldrum peirra boðið hverjum um sig á kynningarfund í leikskólanum. Á fundinum eru leikskólastjóri eða aðstoðarleikskólastjóri, deildarstjóri og foreldrar. Markmið fundarins er að kynnast bakgrunni og högum fjölskyldunnar og reynslu barnsins, t.d. af vistun utan heimilis. Auk pess er leitast eftir að fá fram hvert áhugi barnsins beinist. Leikskólastarfið er einnig kynnt fyrir foreldrum. Á kynningarfundinum fá foreldrar skriflega lýsingu á pátttökuaðlögun. Skipulag aðlögunarinnar byggist á peim hugmyndum um pátttökuaðlögun sem lýst er í handbók Reykjavíkurborgar (2011). Á kynningarfundinum eru foreldrar beðnir að koma með eða senda í leikskólann nokkrar myndir af fjölskyldumeðlimum og öđru pví sem er barninu mikilvægt á heimili pess. Myndirnar eru settar saman í leikskólanum og útbúnar flettibækur sem eru aðgengilegar fyrir börnin á meðan og eftir að formlegu aðlögunarferli lýkur. Tilgangurinn er að tengja heimili og leikskóla og styðja pannig börnin í aðlögunarferlinu.

Gagna í rannsóknina var fyrst og fremst aflað með einstaklings- og rýnihópaviðtölum. Auk pess voru gerðar vettvangsathuganir í leikskólanum. Samtals níu viðtöl voru tekin í rannsókninni. Fimm einstaklingsviðtöl voru tekin við deildarstjóra, leikskólastjóra og starfandi aðstoðarleikskólastjóra. Tvö rýnihópaviðtöl fóru fram, annars vegar við leiðbeinendur og leikskólakennara og hins vegar við deildarstjóra og leikskólakennara sem sinnti stuðningi á einni af deildunum. Vettvangsathuganir voru gerðar í upphafi aðlögunar og einnig eftir að nokkur tími var liðinn frá pví að börnin byrjuðu. Gagnasöfnun fór fram á tímabilinu ágúst 2017 til vors 2019.

Viðtöl við tvo deildarstjóra voru tekin áður en börnin byrjuðu í leikskólanum. Seinni viðtölin prjú við deildarstjórana fóru fram pegar flest barnanna höfðu verið í tvo til prjá mánuði í leikskólanum. Pá voru viðtöl einnig tekin við leikskólastjóra og starfandi aðstoðarleikskólastjóra. Viðtölin voru hálfopin og viðtalsrammi hafður til hliðsjónar, en hann gaf viðmælendum kost á að koma inn á efni sem ekki var í viðtalsrammanum (Kvale og Brinkmann, 2009). Rýnihópaviðtal var tekið í byrjun árs 2018 við prjá leiðbeinendur sem störfuðu á deildunum og leikskólakennara sem sinnti stuðningi á einni deildinni. Á vormánuðum 2019 var tekið rýnihópaviðtal við deildarstjóra einnar deildarinnar og leikskólakennara sem sinnti stuðningi við barn viðkomandi deildar. Í rýnihópaviðtölum er ekki gert ráð fyrir að fólk sé sammála en að samskipti innan hópsins hafi áhrif á hugsanir og hugmyndir pátttakenda (Lichtman, 2013; Litoselliti, 2003). Vettvangsathuganir voru gerðar í leikskólanum í upphafi aðlögunar og sjónum einkum beint að 
samskiptum foreldra, barna og starfsmanna. Athuganir voru einnig gerðar pegar nokkur tími var liðinn frá pví að börnin byrjuðu. Vettvangsathuganirnar voru skráðar niður eftir að heimsókn lauk.

Siðferði í rannsóknum er mikilvægur hluti aðferðafræðinnar. Siðferði fjallar oftast um hvaða hegðun og hugarfar fólks eigi að ríkja í rannsóknum (Sigurður Kristinsson, 2013). Lögð er áhersla á að pátttakendur gefi upplýst og ópvingað sampykki fyrir pátttöku í rannsókn. Einnig að pátttakendum sé heitið fullum trúnaði og tryggt að gögnin séu ekki persónugreinanleg (Lichtman, 2013). Í rannsókninni var tilskilinna leyfa aflað; frá rekstraraðila leikskólans, leikskólastjóra, foreldrum barnanna, deildarstjórum og leiðbeinendum. Til pess að gæta trúnaðar eru pátttakendum og deildum í leikskólanum gefin dulnefni í greininni.

Drátt fyrir að foreldrar hefðu veitt leyfi fyrir hönd barna sinna var mikilvægt að vera meðvitaður um rétt barnanna til að tjá óánægju með veru rannsakanda í leikskólanum og bregðast við í samræmi við tjáningu barnanna (Hrönn Pálmadóttir, 2017).

Á töflu 1 má sjá heiti deilda og nöfn deildarstjóra, leiðbeinenda og leikskólakennara sem tóku pátt í viðtölum, fjölda barna á deild, fjölda barna sem áttu báða eða annað foreldri af erlendum uppruna og fjölda barna sem fengu viðbótarstuðning vegna frávika í proska.

Tafla 1. Deildir, starfsfólk og börn.

\begin{tabular}{lccccc}
\hline Deild & Deildarstjórar & $\begin{array}{c}\text { Leiðbeinendur, } \\
\text { leikskólakennari } \\
\text { stuðningur }\end{array}$ & $\begin{array}{c}\text { Fjöldi barna } \\
\text { á deild }\end{array}$ & $\begin{array}{c}\text { Fjöldi barna } \\
\text { af erlendum } \\
\text { uppruna á deild }\end{array}$ & $\begin{array}{c}\text { Fjöldi } \\
\text { barna með } \\
\text { stuðning }\end{array}$ \\
\hline Hæð & Sigrún & Karen & 11 & 6 & \\
Dalur & Alda & Alina & 9 & 2 & 2 \\
Hlíð & Kristín & $\begin{array}{c}\text { Sæunn, Hjördís/ } \\
\text { stuðningur }\end{array}$ & 15 & 5 & \\
\hline
\end{tabular}

Viðtölin voru afrituð orðrétt, kóðuð og pemagreind. Demagreining er sveigjanleg aðferð sem notuð er til að skipuleggja og greina gögn (Braun og Clarke, 2013). Greining gagnanna fór fram í nokkrum prepum. Svör og umræður viðmælenda voru kóðuð í ljósi rannsóknarspurninganna og leitast var við að kanna pá merkingu sem pátttakendur lögðu í viðfangsefnið sem til rannsóknar var. Vettvangsathuganir voru einnig kóðaðar og pemagreindar og leitað að sams konar pemum og höfðu komið fram í viðtölunum. Að bví búnu voru sett saman pemu sem lýsa endurteknum mynstrum innan gagnasafnsins. Við úrvinnslu gagna var lögð áhersla á atriði eða mynstur sem gætu gefið vísbendingar um fleti sem væru mikilvægir í augum pátttakenda eða birtust í vettvangsathugunum.

Meðan á rannsókninni stóð áttu sér stað talsverðar breytingar í starfsmannahaldi á deildunum. Einn deildarstjóranna fór í barnsburðarleyfi og ekki fékkst leikskólakennari í stöðuna. Auk pess tók einn deildarstjóranna að sér stöðu aðstoðarleikskólastjóra. Í hans stað kom leikskólakennari.

\section{Niðurstöður}

Hér á eftir verður gefin innsýn í pá merkingu sem leikskólakennarar og leiðbeinendur lögðu í upphaf leikskólagöngu barna með fjölbreyttan bakgrunn og menningu ásamt peim leiðum sem farnar voru í leikskólanum í aðlögunarferlinu og til að skapa samfellu í lífi barnanna. 


\section{Aðlögunarferlið}

Leikskólakennarar lýstu hlutverki sínu í aðlögunarferlinu sem tvípættu. Annars vegar fólst pað í að koma á og viðhalda tilfinningalegum tengslum við foreldra og börn. Hins vegar snerist pað um skipulagningu aðlögunar, að halda kynningarfund með foreldrum, hafa yfirsýn í aðlögunarferlinu, ýta undir samstarf innan deilda og miðla pekkingu til samstarfsfólksins. Leiðbeinendur ræddu um virka pátttöku sína í sjálfu aðlögunarferlinu og eftir að formlegri aðlögun lauk. Allir viðmælendur lögðu áherslu á að skipulag aðlögunar ætti að einkennast af sveigjanleika par sem börn gætu haft áhrif. Einnig var litið svo á að aðlögunarferlið væri sameiginlegt námsferli starfsfólks, foreldra og barna.

\section{Tilfinningaleg tengsl og samskipti}

Allir viðmælendur litu svo á að pað væri á ábyrgð starfsmanna leikskólans að mynda tengsl og skapa traust foreldra við upphaf leikskólagöngu. Рað gæti tekið tilfinningalega á að setja barn sitt í leikskóla og pví væri mikilvægt að setja sig í spor foreldra og taka tillit til pess að bakgrunnur og reynsla fjölskyldna væri ólík. Foreldrar með sitt fyrsta barn væru gjarnan óöruggir með að láta barn sitt frá sér. Dað tæki tíma að skapa traust milli leikskóla og foreldra og starfsfólk pyrfti að leggja sig fram og tileinka sér opin samskipti við foreldra svo peir fyndu að peim væri óhætt að skilja barnið sitt eftir í leikskólanum.

Fram kom hjá viðmælendum að erlendir foreldrar væru gjarnan í viðkvæmri stöðu par sem peir hefðu oft ekki pekkingu eða reynslu af íslenskum leikskólum og hefðu sig pví minna í frammi en íslenskir foreldrar. Sólveig leikskólastjóri lagði mikla áherslu á að leikskólinn væri traustvekjandi fyrir alla foreldra. Hún kaus fremur að hringja í foreldra en að senda tölvupóst til að finna heppilegan tíma fyrir fyrsta kynningarfund. Ef um erlendar fjölskyldur væri að ræða væri í samtalinu rætt um að fá túlk á fundinn. Í framhaldi væri túlkur pantaður og helst einnig hálfan fyrsta dag fjölskyldunnar í leikskólanum.

Tungumálið er mikilvægt pegar kemur að samskiptum og brýnt er að leita allra leiða til að koma á tengslum við foreldra. Sigrún, deildarstjóri á Hæð, lýsti pví:

Við hikum ekki við að fá túlka. Nýtum líka mannauðinn af pví að petta snýst allt saman um barnið. Snýst um að barninu og fjölskyldunni líði vel hérna hjá okkur.Við erum með pólskumælandi starfsfólk og nýtum pað sem við höfum.Við reynum eftir fremsta megni að allir fái sömu upplýsingar og að pau fái pað sem pau purfa.

Margir viðmælendur nefndu að aðlögunin tæki lengri tíma fyrir börn með erlendan bakgrunn en fyrir íslensk börn. Alina, leiðbeinandi á Hæð, sem er sjálf af erlendum uppruna, vísaði í eigin reynslu og sagðist taka eftir að börn og foreldrar af erlendum uppruna ættu oft erfitt með aðlögunina í byrjun. Hún sagði:

Баð eru meiri tengsl milli barna og foreldra af erlendum uppruna. Detta er mynstur, hugsanlega meiri tengsl og pau treysta ekki strax öðru fólki. En smám saman gengur pað vel, pegar pau sjá að pað er vel hugsað um börnin peirra.

Alina hélt áfram: „Degar ég sé petta pá sýni ég í verki og sinni barninu sérstaklega til pess að öðlast traust foreldranna. Ég vil vera í góðum tengslum við pau.“

Eftir að formlegri aðlögun lýkur reynist kveðjustundin á morgnana erfið fyrir sum börn og foreldra. Lögð var áhersla á að foreldrar kveddu börnin sín en peir gætu jafnframt treyst starfsfólki til að láta vita um líðan barnsins eftir að peir færu. Hringt væri í foreldra eða myndir sendar í tölvupósti pegar barnið væri búið að jafna sig. Í pví sambandi væri mikilvægt að myndirnar sýndu barnið par sem pví liði vel og pað væri pátttakandi í einhverju skemmtilegu í leikskólanum. Alda deildarstjóri sagði: „Hringjum, sendum myndir, til að pau séu ekki í vinnunni eða heima að hafa áhyggjur." 


\section{Kynningarfundur}

Á kynningarfundinum sem venjulega er haldinn með foreldrum hvers barns sem er að byrja í leikskólanum er lagður grunnur að aðlögun og áframhaldandi samstarfi um barnið. Að sögn Sólveigar leikskólastjóra er tilgangur fundarins fyrst og fremst að fá innsýn í líf og reynslu barnanna, svo sem venjur, mataræði, veikindi, svefn og áhugasvið. Dannig er hægt að mæta pörfum fjölskyldunnar betur en ella og skipuleggja aðlögun barnsins í samstarfi við foreldra. Sólveig sagði: „Við erum að vinna með fjölskyldum, ekki aðeins okkar módel og pau verða að passa inn í pað - við erum saman í pessu, fjölskyldan og skólinn." Í ljósi upplýsinga sem fást á kynningarfundinum er t.d. hægt að tryggja að uppáhaldsleikefni barnsins sé fyrir hendi pegar pað byrjar í leikskólanum. Kristín, deildarstjóri á Hlíð, gaf dæmi: „,.. pað var ein sem elskar kisur ... Pá reyndi maður að skoða kisur [myndabók] með henni.“

Stjórnendur töluðu einnig um mikilvægi pess að ræða væntingar foreldra til leikskólans og að veita upplýsingar um sérstöðu íslenskra leikskóla. Erlendir foreldrar pyrftu að fá upplýsingar, t.d. varðandi útivist og fatnað sem börnin klæddust. Stundum pyrfti að benda foreldrum á hvar hægt væri að nálgast slíkan fatnað. Einnig pyrftu foreldrar að fá upplýsingar um að leikskólinn væri bæði mennta- og pjónustustofnun. Sólveig leikskólastjóri sagði að stundum pyrfti „langan tíma í að útskýra hvernig börn læra og hvaða stefna er rekin á Íslandi hvað pað varðar.“”

Foreldrar eru beðnir að koma með eða senda fáeinar myndir, t.d. af fjölskyldumeðlimum og öðru mikilvægu í umhverfi barnsins heima. Myndirnar eru plastaðar í leikskólanum og settar upp á hring pannig að pær mynda eins konar flettibók. Eftir að formlegri aðlögun lýkur eru flettibækurnar aðgengilegar fyrir börnin meðan pau parfnast peirra. Sæunn, leiðbeinandi á Hlíð, sagði: „, Dau eru nánast hæett að nota pær í dag en pær voru rosalega mikið notaðar fyrst. Pað voru bara sum börn sem voru með pessar bækur allan daginn.“

Á kynningarfundinum fá foreldrar î hendur plagg um pátttökuaðlögun par sem tilgangi aðlögunar, framkvæmd og hlutverki foreldra er lýst. Jafnframt er lögð áhersla á pað við foreldra að plaggið sé til viðmiðunar og ferlið sé metið jafnt og pétt.

\section{Skipulag og sveigjanleiki}

Sú leið er farin íleikskólanum að skipta börnum og foreldrum peirra niðuráákveðna lykilstarfsmenn innan deildanna. Баð er venjulega gert eftir kynningarfundinn. Sólveig leikskólastjóri sagði tilganginn með lykilstarfsmönnum vera eftirfarandi:

... að mynda bara ákveðið öryggi og fyrstu prjá mánuðina finnst mér pað mjög mikilvægt að barnið nái að mynda tengsl. Eins árs gamalt barn, eða 18 mánaða og pess vegna tveggja ára barn, að pað hafi einhvern sem pað getur leitað til.

Deildarstjórar deila ábyrgð á fjölskyldum milli starfsmanna og peir töluðu um mikilvægi góðs samstarfs innan deildar. Upplýsa pyrfti samstarfsfólk, hafa yfirsýn yfir barnahópinn og fylgjast með framvindu aðlögunar. Sigrún, deildarstjóri á Hæð, sagði: „Við útbjuggum hefti um aðlögun fyrir starfsfólk, hvers vegna aðlögun, hvaða leið viljum við fara hér og um lykilpersónu, hvað gerir hún, til að stilla saman strengi.“”

Fram kom í máli allra viðmælenda að prátt fyrir að ákveðið skipulag væri sett upp á deildunum áður en börnin byrjuðu skipti sveigjanleiki öllu máli og samstarf milli leikskóla og fjölskyldu væri aðalatriðið. Hvert barn væri einstakt og aðlögunin ætti að mótast af vellíðan barnsins í leikskólanum. Рað gæti t.d. verið erfitt að ákveða fyrir fram og gefa sér að barnið tengdist pessum ákveðna lykilstarfsmanni sem valinn væri af deildarstjóra. Sæunn, leiðbeinandi á Hlíð, lýsti pví hvernig börnin gætu haft áhrif á fyrir fram ákveðið skipulag: „Баð var held ég bara Jón sem átti svona erfiða aðlögun, ég átti að vera lykilpersónan hans en hann leitaði miklu meira til Stefaníu pannig að við skiptum.“ 
Flestir viðmælendur voru ánægðir með pær leiðir sem farnar voru í aðlögunarferlinu. Sólveig leikskólastjóri hafði velt fyrir sér hvernig pátttökuaðlögun reyndist fyrir erlenda foreldra:

... óörugg, er að koma ný til landsins og pví meira sem íslenski foreldrahópurinn er opinn pá getur hún lent til hliðar. Ég hef oft hugsað pað að pau komi bara ein í rólegheitum par sem ekki er verið að sinna premur öðrum börnum, heldur pá er maður á mann í pessari aðlögun með túlkinum. Pannig hef ég oft hugsað pað, hvort við hérna ættum að spá í pad.

Kristín, deildarstjóri á Hlíð, lýsti fyrirkomulagi á pátttökuaðlögun á sinni deild: „Börnin voru tekin inn í premur hópum. Pá er hvert barn búið að fá sína tengslapersónu sem er með peim í matartíma, hvíld og könnunarleik." Hins vegar sagði Alda, deildarstjóri á Dal, að pað hefði ekki verið auðvelt að koma við pátttökuaðlögun og lykilpersónu fyrir hverja fjölskyldu á deildinni um haustið. Sökum manneklu hefðu ekki verið tök á að halda kynningarfundi með foreldrum hvers og eins barns í leikskólanum. Börnin hefðu pví byrjað öll í einu eftir einn almennan kynningarfund fyrir foreldra. Allt of margir hefðu pví verið í aðlögun á sama tíma og erfitt að sinna hverri og einni fjölskyldu. Hún lýsti reynslu sinni:

Pannig kom t.d. ekki í ljós fyrr en eitt barn var búið að vera hjá mér í hálfan mánuð að hann hafði aldrei verið hjá dagmömmu og hafði hætt á brjósti 10 dögum áður en hann byrjaði í leikskóla.

Eftir fund með foreldrum var sett upp ferli sem byggðist á að stytta veru barnsins í leikskólanum og styrkja tengsl og traust milli foreldra og deildarstjóra.

Í máli allra viðmælenda kom fram að til að tryggja vellíðan barna í aðlögunarferlinu og draga úr álagi á starfsfólk pyrfti að deila hópnum niður í fámenna hópa í inntöku í leikskólann. Ef vel ætti að vera pyrftu að líða allt að prjár vikur á milli inntöku nýrra hópa. Mikilvægt væri að hafa náð að skapa peim börnum sem fyrir væru á deildinni tilfinningalegt öryggi pegar nýir barnahópar byrjuðu.

Breytingar í starfsmannahaldi, sem áttu sér stað pegar líða tók á haustið, höfðu áhrifá aðlögunarferli og vellíðan fáeinna barna. Börnin áttu pá í meiri erfiðleikum en ella með að kveðja foreldra sína. Mikilvægt hefði verið að bregðast við pessu og veita börnunum meiri einstaklingsumhyggju og tengsl við pá starfsmenn sem voru eftir á deildinni, en pað hefði aftur á móti skapað aukið álag á pá starfsmenn.

\section{Sameiginlegt námsferli}

Í hugum starfsmanna var pátttökuaðlögun sameiginlegt námsferli barna, foreldra og starfsmanna. Ferlið tekur langan tíma og haft var á orði að aðlögun væri í raun meginstefið í pví sem ætti sér stað í leikskólanum fram að áramótum. Sigrún, deildarstjóri á Hæð, lýsti aðlöguninni sem fjölskylduaðlögun par sem börn og foreldrar væru saman að læra á leikskólalífið og öryggi barna og foreldra væri samofið. Kosturinn við aðlögunina væri einnig sá að starfsfólki gæfist tækifæri til að kynnast foreldrum og læra af peim. Dannig væri leitast við að virða pekkingu foreldra á barninu. Sæunn, leiðbeinandi á Hlíð, tók undir pessi viðhorf og sagði: „Gott að hafa foreldra með 1 aðlögun, peir gátu séð hvernig starfið fer fram og peir voru öruggir sem er ekki síður mikilvægt svo börnin verði örugg. Peir gátu kynnst okkur og við gátum kynnst foreldrum.“

Fyrstu dagana með foreldrunum sagðist Sigrún, deildarstjóri á Hæð, leggja áherslu á pað við foreldra að „,... bara leyfa börnunum að verða örugg hér, að vera ekki að ýta peim stöđugt frá sér, farðu núna og leiktu við petta, heldur leyfa peim að skoða og kanna og sjá ný andlit í öruggum faðmi.“ Eftirfarandi lýsing úr vettvangsnótum sýnir hvernig börnin kanna leikskólaumhverfið með foreldra sína í bakgrunni á fyrsta degi aðlögunar: 
Fimm börn og foreldrar peirra eru í aðlögun. Foreldrar sitja ýmist á dýnu eða á lágum stólum. Smám saman fóru börnin að færa sig frá foreldrum og skoða ýmis leikföng, dýr og kubba en mörg peirra skruppu í fang öðru hverju. Tvær stelpur struku hvor annarri vinalega. Stelpa af erlendum uppruna fór mjög hægt í sakirnar og horfði rannsakandi í kringum sig en foreldrarnir fylgdust vel með en ýttu ekki á hana (Vettvangsnótur í september 2018).

Allir viðmælendur nefndu hvíld sem viðkvæma stund í aðlögunarferlinu. Á fjórða og síðasta degi aðlögunar er stefnt að pví að foreldrar taki virkan pátt í að láta börn sín leggjast og hvíla sig. Foreldrar efast gjarnan um að börn peirra sofni í peim aðstæðum sem peim er boðið upp á í leikskólanum, en börnin liggja pétt saman á lágu fleti, sem er mjög ólíkt aðstæðum heima fyrir. Hjördís, leikskólakennari á Hlíð, sem hafði ekki upplifað pátttökuaðlögun áður, sagði:

Við nýttum pað sérstaklega, eins og með hvíldina, að hafa foreldrana inni í hvíldinni og sjá hvernig pau gera. Allt öđruvísi svona hvíldaraðlögun heldur en ég hef verið vön frá pví áður ... pað voru parna nokkur börn sem sofnuðu ekki í hvíldinni með foreldrum sínum og pau voru bara ljúfust sem lömb, sofnuðu strax hjá okkur.

Samstarf starfsfólks innan deilda og milli deilda var stjórnendum hugleikið, svo og mikilvægi pess að finna leiðir til að próa starfshætti með yngstu börnunum. Kristín, deildarstjóri á Hlíð, sagði frá pví að starfsmenn deildarinnar hefou ígrundað í sameiningu hvernig til hefði tekist í aðlögunarferlinu og með tengsl peirra við börnin. Niðurstaðan var sú að lykilstarfsmenn fóru að flytja sig á milli borða í matartíma á hálfsmánaðarfresti. Hún sagði:

Við vildum fá betri yfirsýn og fara meira á milli hópa, en gera pað ekki fyrr en pau væru orðin frekar örugg í aðstæðum og ákváðum að byrja petta núna, pegar fyrsti hópurinn var búinn að vera í prjá mánuði.

Hjördís leikskólakennari var sammála Kristínu um að börnin hefðu verið tilbúin og tekið breytingunum vel, en aðeins eitt barn hefði purft stuðning við að venjast pessu.

\section{Samfella milli heimilis og leikskóla}

Niðurstöður sýna að litið var svo á að eftir að formlegri aðlögun lyki væri pað áfram hlutverk leikskólans að viðhalda tengslum og samfellu milli leikskóla og heimilis barnanna. Leikskólinn yrði að viðurkenna og endurspegla ólíkan bakgrunn og menningu barnanna. Leita pyrfti leiða til að allir foreldrar upplifðu pátttöku og að tilheyra daglegu lífi og námi barna sinna í leikskólanum.

Að taka pátt og tilheyra

Dagleg samskipti við foreldra voru talin mikilvæg til pess að styrkja tengsl milli leikskóla og fjölskyldna og veita peim innsýn í líf barnsins í leikskólanum.

Hjördís leikskólakennari orðaði pað svo: „Mér finnst pað vera í okkar höndum að eiga frumkvæðið pannig að ef við gerum pað pá finnst mér foreldrar oftast vera tilbúnir til pess einmitt að koma, og tala meira við okkur." Mikilvægt væri að segja foreldrum frá framförum barna peirra. Guðrún, leiðbeinandi á Dal, sagði: „Ég læt bara vita hvort pað sé eitthvað lag sem honum finnst rosalega gaman að hlusta á eða syngja. Pegar maður uppgötvar eitthvað nýtt um barnið pá alveg hiklaust læt ég vita.“

Í máli viðmælenda kom fram að leikskólinn yrði að viðurkenna og endurspegla margbreytileikann og ólík tungumál barnanna. Foreldrar og börn af erlendum uppruna pyrftu jafnt og aðrir að finna að pau væru pátttakendur og tilheyrðu leikskólanum. Рað væri pví í höndum starfsfólks að finna leiðir til að nálgast foreldrana og gefa peim innsýn í starfið. Lögð væri áhersla á myndrænar upplýsingar til að leiðbeina og upplýsa foreldra af erlendum uppruna um viðburði í leikskólanum. 
Jafnframt pyrfti að virða heimamál fjölskyldnanna í leikskólanum. Í peim tilgangi voru foreldrar barnanna sem voru með annað tungumál en íslensku beðnir að skrifa orð til að merkja ýmsa staði innan leikskólans, svo sem skrifstofu, salerni og leikherbergi.

Samskiptabækur sem fara á milli leikskóla og heimilis eru gjarnan notaðar pegar um erlend börn er að ræða. Einnig er petta gert ef sérstök ástæða pykir til að ýta undir vellíðan barnanna. Samskiptabækurnar eru sendar á milli skóla og heimilis og settar inn myndir af athöfnum barnsins með stuttum texta, gjarnan á íslensku og ensku. Foreldrar voru hvattir til að skoða og tala um myndirnar við börnin og jafnframt setja í bókina myndir af atburðum heima fyrir. Kostir pessa samskiptamáta komu glögglega í ljós pegar telpu af erlendum uppruna hafði verið úthlutað lykilstarfsmanni sem einnig var af erlendum uppruna. Barnið sýndi fljótlega sterk merki um hræðslu og tjáđi móðir hennar deildarstjóra, með aðstoð túlks, að telpan hefði ekki séð dökka manneskju áđur. Í framhaldi var ákveðið að setja inn myndir í samskiptabókina par sem telpan og starfsmaðurinn voru saman í ýmsum ánægjulegum aðstæðum í leikskólanum, t.d. við matarborð og að mála saman. Bókin fór á milli leikskóla og heimilis og gafst foreldrum tækifæri til að skoða hana og ræða við barnið. Smám saman dró úr hræðslu telpunnar og hún tengdist lykilstarfsmanninum.

Dátttakendur voru sammála um að hægt væri að merkja pað pegar börn og foreldrar upplifðu að pau væru pátttakendur í leikskólanum. Jafnvel mætti líta svo á að aðlögun væri lokið pegar foreldrar væru farnir að veita hlutdeild í lífi sínu og deila sögum að heiman með starfsfólki. Einnig væri pað merki um petta pegar foreldrar segðu frá breytingum sem yrðu á högum fjölskyldunnar. Dá hefði myndast traust og börn og foreldrar gæfu til kynna að leikskólinn væri hluti af tilveru peirra. Petta sæist t.d. pegar börnin kæmu á morgnana og sýndu með líkamstjáningu að pau væru glöð og ánægð. Sigrún deildarstjóri sagði:

Degar pað er komin pessi gagnkvæma ánægja að hittast. Komið petta flæði á milli, foreldrar eru að segja „,pað var yndislegt um helgina, við gerðum petta og petta“. Börnin eru að koma svona inn sátt og hérna, pó svo, jú, stundum parf maður knús og svoleiðis, maður hættir pví ekki.

Degar leið á haustið fékk hvert barn á deildunum sína skráningarbók par sem tilgangurinn var að skrá og sýna með markvissum hætti námsferli barnanna í myndum og máli. Foreldrar voru hvattir til að nýta sér petta til að setja inn lýsingar í bókina á pví sem börnin og fjölskyldan tækju sér fyrir hendur heima. Dátttaka foreldra hafði verið misjöfn og í raun höfðu fremur fáir foreldrar nýtt sér pennan möguleika.

\section{Öflugir námsmenn}

Nokkrir viðmælendur sem höfðu haft litla reynslu af starfi með ungum börnum áður greindu frá hvernig viðhorf til getu barnanna breyttust. Sigrún deildarstjóri lýsti sinni reynslu:

Dau eru svo prautseig, endalaust að reyna aftur og aftur ... pau eru svo miklu hæfari en margir gera ráð fyrir og par á meðal ég á peim tíma. Pau eru svo móttækileg, pau eru svo áhugasöm, pau vilja læra og vilja gera.

Degar leið á haustið beindist starf deildarstjóranna æ meir að pví að skipuleggja námsumhverfi barnanna í ljósi pess hver barnahópurinn var og hvert áhugi barnanna beindist. Á hverjum degi voru svokallaðar flæðistundir par sem börnin gátu farið á milli mismunandi svæða á deildinni par sem ólík viðfangsefni voru á boðstólum. Starfsfólkið skipti sér niður á svæðin og studdi börnin í samskiptum og leik. Í vettvangsnótum má sjá dæmi um hvernig börnin nýttu sér flæðistund og stuðning kennara. 
Tvö börn, með málningarsvuntur, stóðu við borð og máluðu köngla með gulri málningu. Nokkur börn horfðu áhugasöm á. Kennari aðstoðaði börnin. Einingakubbar voru á mottu á gólfinu og par sat annar kennari. Börnin fóru pangað eftir að hafa horft á málarana í smástund. Kennarinn raðaði kubbum upp og börnin gerðu eins, hún talaði líka í símann við börnin og notaði kubb til pess. Á ganginum var ýmislegt í boði til hreyfingar, svo sem boltar og trévagn, og par var einn kennari. Í byrjun voru par engin börn en svo komu börnin pangað eitt og eitt (Vettvangsnótur í febrúar 2019).

Að mati allra viðmælenda höfðu börnin lært mikið og tekið framförum pá mánuði sem pau höfðu verið í leikskólanum. Öryggi peirra, tengsl og vinátta hafði eflst mikið. Alina sagði: „Đau eiga orðið í vinasamböndum við hvert annað og líka við eldri börnin." Guðrún tók undir og bætti við:

Mér finnst svo gaman að sjá. Pau byrjuðu svo ung og svo gaman að fylgjast með stóru krökkunum að hjálpa litlu krökkunum. Litlu krakkarnir að elta stóru krakkana. Mjög skemmtileg dýnamík.

\section{Umræða og lokaorð}

Niðurstöður rannsóknarinnar varpa ljósi á að upphaf leikskólagöngu snertir marga fleti leikskólastarfsins. Rannsóknin gefur innsýn í reynslu starfsmanna og viðhorf peirra til fjölskyldna með fjölbreyttan bakgrunn og menningu. Auk pess koma fram viðhorf til hæfni og getu ungra barna og starfshættir sem taldir eru ákjósanlegir til að skapa samfellu í lífi barnanna. Áherslur í aðlögunarferlinu endurspegla heildræna sýn á fjölskylduna par sem litið er á öryggi og vellíðan foreldra og barna sem samtvinnaðan pátt.

Í niðurstöðum birtist skýr greinarmunur á hlutverki faglegra stjórnenda leikskólans og leiðbeinenda á deildum við upphaf leikskólagöngu. Stjórnendur, p.e. leikskólastjóri, aðstoðarleikskólastjóri og deildarstjórar, sáu um undirbúning og skipulagningu aðlögunar. Jafnframt var pað peirra hlutverk að upplýsa starfsfólk um tilgang peirra leiða sem valdar voru við upphaf leikskólagöngunnar. Einnig snerist faglegt hlutverk stjórnenda um að mynda tengsl við börn og foreldra og hafa yfirsýn yfir framgang aðlögunarferlisins á deildunum. Detta er í samræmi við rannsókn Hostettler Schärer (2018) par sem leikskólakennarar túlkuðu faglegt hlutverk sitt með svipuðum hæetti.

Pátttökuaðlögun var talin reynast vel sem sameiginlegt námsferli foreldra, barna og leikskólastarfsfólks. Hins vegar komu fram vísbendingar pess efnis að foreldrar sem ekki hefðu tök á íslensku ættu frekar í erfiðleikum með pátttöku og að börn af erlendum uppruna upplifðu í mörgum tilvikum erfiðari aðlögun en börn íslenskra foreldra. Margetts (2014) bendir á að pví meiri breytingar sem fjölskyldan parf að takast á við í upphafi leikskólagöngu, peim mun erfiðari getur umbreytingin orðið. Detta er einnig í samræmi við aðrar rannsóknir sem sýna að foreldrar af erlendum uppruna upplifa jaðarsetningu gagnvart ríkjandi menningu leikskóla (Chan og Ritchie, 2016) og að tungumálaerfiðleikar geti hindrað samskipti (Arna H. Jónsdóttir og Jóhanna Einarsdóttir, 2017; Hedlin, 2017). Sjónarmið allra foreldra og pekking peirra á barninu eru mikilvægur grunnur samstarfsins og stuðla að áhrifum peirra á leikskólastarfið. Í ljósi pess að tilgangur pátttökuaðlögunar er ekki síst sá að reynsla foreldra skapi öryggi sem hafi áhrif á börnin og aðlögun peirra (Kristín Dýrfjörð, 2009) parf að tryggja að menningar- og félagslegt samhengi fjölskyldna sé lagt til grundvallar í skipulagi aðlögunarferlisins. Í skýrslu OECD (2017) er bent á að samstarf við foreldra sé mikilvægur páttur gæðastarfs í leikskólum og pað sé réttur allra foreldra að hafa eitthvað um nám barna sinna að segja. Niðurstöður rannsóknarinnar benda til pess að vert sé að skoða enn frekar samsetningu fjölskyldna og fjölda barna sem eru í aðlögun samtímis, auk pess að tíminn sem líður milli pess að hópar eru teknir inn í leikskólann sé nægur.

Í rannsókninni kom fram að allir pátttakendur lögðu áherslu á ábyrgð sína á að skapa tilfinningaleg tengsl við foreldra og börn. Sveigjanleiki og opin samskipti voru talin lykilatriði í að tryggja 
vellíðan peirra. Sveigjanleiki var einnig talinn mikilvægur gagnvart börnunum. Litið var á börnin sem öfluga námsmenn sem hefðu áhrif á daglegt líf sitt í leikskólanum. Dannig gátu börnin t.d. haft áhrif á val á lykilpersónu ef peim hugnaðist svo, prátt fyrir að annað hefði verið ákveðið upphaflega. Раð rímar við bernskurannsóknir par sem bent er á að börn séu mikils megnug og skapandi (Dahlberg og Moss, 2005; Jóhanna Einarsdóttir, 2012). Detta er einnig í samræmi við niðurstöður annarra rannsókna (Elfer, 2006, 2012; Traum og Moran, 2016) par sem bent er á að tilfinningaleg tengsl, félagsleg samskipti og einstaklingsmiðun purfi að fara saman í upphafi leikskólagöngu.

Við skipulagningu á námsumhverfi og námsreynslu barnanna var áhersla lögð á að byggja á áhuga peirra og að börn lærðu hvert af öðru í leikskólanum. Detta rímar við hugmyndir sem fram koma í rannsóknum á páttaskilum milli leik- og grunnskóla, par sem lögð er áhersla á samfellu í reynslu barna og að námsumhverfi og námskrá eigi að byggjast á fjölbreyttum áhuga peirra (Dockett og Jóhanna Einarsdóttir, 2017; ETC, 2011). Litið var á framfarir barnanna í námi sem vettvang fyrir miðlun til foreldra og til að skapa menningarlega samfellu milli leikskóla og heimilis. Par má nefna flettibækur, samskiptabækur og skráningar á námi barnanna í máli og myndum, merkingar á svæðum í leikskólanum á tungumáli barnanna og notkun túlkapjónustu. Auk pess voru erlendir starfsmenn nýttir sem pátttakendur í upplýsingamiðlun til foreldra. Hins vegar er ljóst að dagleg miðlun og samskipti við fjölskyldur af erlendum uppruna geta verið flókin. Að viðhalda tengslum við foreldra er samfellt ferli sem lýkur ekki pegar formlegri aðlögun er lokið. Rannsóknin sýnir аð pað er fagleg áskorun fyrir leikskóla að próa frá upphafi leikskólagöngu starfshætti sem ýta undir menningarlega samfellu í lífi barna ásamt að stuðla að pví að allar fjölskyldur upplifi sig sem pátttakendur og að pær tilheyri nýja umhverfinu.

Dað er alvarlegt umhugsunarefni að ytri pæettir, svo sem erfiðleikar við að ráða inn leikskólakennara eða annað hæft starfsfólk að hausti og skortur á stöðugleika í starfsmannahaldi, höfðu áhrif á aðlögun og vellíðan sumra barna og foreldra fyrstu mánuði barnanna í leikskólanum. Aðstæðurnar leiddu til pess að skipulag og faglegar ákvarðanir stjórnenda um framkvæmd aðlögunar, t.d. að allir foreldrar fengju lykilstarfsmann sem sinnti peim sérstaklega, sem og pátttökuaðlögun, nádu ekki fram að ganga á öllum deildum. Einnig sköpuðu pessar aðstæður mikið álag á pað starfsfólk sem eftir var á deildunum. Pað gefur auga leið að slíkar aðstæður hafa áhrif á gæði í leikskólastarfi og draga úr líkum á að leikskólinn geti af fagmennsku tekist á við mikilvæg verkefni og komið til móts við pau áform sem stjórnvöld landsins hafa um inntöku ungra barna í leikskóla.

Rannsóknin var styrkt af rannsóknarsjóði Háskóla Íslands. 


\section{Educators' views on transition from home to preschool}

The aim of the article is to shed light on the attitudes and experiences of educators in a preschool in Reykjavík, in collaboration with parents and children with diverse backgrounds and cultures, in the transition to preschool. The purpose is to understand the meaning of this aspect of the work and thus add to existing knowledge. The ideological foundation of the study is largely drawn from scholars who have studied the changes that occur when children begin compulsory schooling. Although the research mainly focuses on the beginning of primary schooling, it can be argued that many of the same factors also apply to the onset of preschool for young children. Children are considered to be powerful and creative, and the learning environment and curriculum should be based on children's interests and circumstances and take into account that they are different (Dockett \& Einarsdóttir, 2017; Dunlop, 2017; Educational Transitions and Change Research group, 2011). Thus, continuity in children's lives should allow for the experience of the children's homes in their transition to preschool (Margetts, 2002). The changes are characterized by a complex process in which the concepts of transition and adaptation are intertwined. The process of adaptation begins at home and continues until the child and his or her family experience themselves as participants and belong to the new environment (Margetts, 2014). The child is moving from one environment to another, from home or day-care to a new place: the preschool. The process is considered to be an integrated learning experience for children, parents and preschool teachers (Drugli \& Undheim, 2011). The article aims to answer two questions:

- What are the views of educators working with children with diverse backgrounds and cultures in the transition to preschool?

- How is the preschool emphasizing the continuity of the children's lives?

The preschool that participated in the study has extensive experience in working with families of foreign origin. Children under the age of two started in three units in the fall. Five individual interviews were conducted with the unit leaders. Interviews with two of them were carried out in August, before the children's transition to preschool. The second phase of interviews took place when most of the children had been in the preschool for two to three months. Interviews were also conducted with the preschool principal and the acting assistant principal. All the interviews were semi-structured (Kvale \& Brinkmann, 2009). Two focus group interviews were conducted; on the one hand, with the personnel who worked with the children, and, on the other, with one of the unit leaders and a preschool teacher who supported a child in one of the groups. In focus group interviews, it is not assumed that people agree but that within-group communication influences participants' thoughts and ideas (Lichtman, 2013; Litoselliti, 2003). Observations were made at the beginning of the children's start in the preschool, where the focus was mainly on communication between parents, children and staff. Observations were also made when some time had passed since the children started. The formal analysis process was inspired by thematic analysis. Thematic analysis, according to Braun and Clarke (2013), is a flexible method of organising and analysing data to identify and describe repeated patterns or themes within a set.

The findings revealed that professionals described their role in the transition process as twofold. Establishing and maintaining emotional relationships with parents and children was important. Furthermore, having an overview, fostering collaboration within the units and disseminating knowledge to colleagues was also essential. Other staff working with children discussed active participation in the transition process 
and maintaining relationships with the children's parents after the formal transition was completed. Parental participation in the transition process was considered to be successful as a joint learning process for parents, children and preschool staff. However, there were indications that parents who did not speak Icelandic had difficulties in participating. Also, that children of foreign origin in many cases experienced a more difficult transition than children of Icelandic parents. The study shows that it is a professional challenge for preschool educators to develop, from the beginning, a pedagogical approach that contributes to all families experiencing themselves as participants and belonging to the new environment.

Key words: Preschool, transition, educators, diverse background and culture

\section{Um höfund}

Hrönn Pálmadóttir (hropalm@hi.is) er dósent við Menntavísindasvið Háskóla Íslands. Hún lauk doktorsprófi í menntunarfræði ungra barna frá Háskóla Íslands árið 2015. Helstu áherslusvið í rannsóknum eru sjónarhorn yngstu leikskólabarnanna á samskipti og leik ásamt upphafi leikskólagöngu fjölbreytts hóps barna. Hrönn hefur tekið pátt í bæði norrænum og alljóðlegum rannsóknarverkefnum um margvíslegar áskoranir í daglegu lífi barna í leikskólum.

\section{About the author}

Dr. Hrönn Pálmadóttir (hropalm@hi.is) is an Associate Professor of Early Childhood Education and Care at the School of Education, University of Iceland. She has broad experience in the field of early childhood education and early childhood teacher education. The main focus in her current research is the youngest children's perspectives on their preschool experiences and transition from home to preschool. Pálmadóttir has been involved both in Nordic and international research projects on various issues and challenges to children's everyday lives in preschools.

\section{Heimildir}

Alvestad, T., Bergem, H., Eide, B., Johansson, J.-E., Os, E., Pálmadóttir, H., ...Winger, N. (2013). Challenges and dilemmas expressed by teachers working in toddler groups in the Nordic countries. Early Child Development and Care, 184(5), 671-678. doi:10.1080/03004430.2013.807607

Anna Lilja Sævarsdóttir, Anna Elísa Hreiðarsdóttir og Hermína Gunnpórsdóttir. (2013). Foreldrasamstarf og fjölmenning. Samskipti deildarstjóra við erlenda foreldra sem ekki tala íslensku. Netla - Veftímarit um uppeldi og menntun. Sótt af http://netla.hi.is/greinar/2013/ryn/016.pdf

Arna H. Jónsdóttir, Bryndís Garðarsdóttir og Jóhanna Einarsdóttir. (2013). Leikskólabyrjun og lengd dvalartíma: Sjónarmið leikskólakennara og leiðbeinenda. Sérrit Netlu 2013 - Rannsóknir og skólastarf. Sótt af http://netla.hi.is/serrit/2013/rannsoknir_og_skolastarf/001.pdf

Arna H. Jónsdóttir og Jóhanna Einarsdóttir. (2017). Áherslur og valdatengsl í samstarfi starfsfólks og foreldra í leikskólum. Sérrit Netlu 2017 - Innsýn í leikskólastarf. Sótt af http://netla.hi.is/serrit/2017/innsyn_leikskolastarf/004.pdf

Belsky, J. (2009). Early day care and infant-mother attachment security. Encyclopedia on early childhood development. Sótt af http://enfant-encyclopedie.com/Pages/PDF/BelskyANGxp-Attachment.pdf

Berns, R. (2007). Child, family, school, community: Socialization and support. Belmont:Thomson/Wadsworth. 
Bjørnestad, E. og Pramling Samuelsson, I. (2012). Hva betyr livet i barnehagen for barn under 3 år? En forskningoversigt. Oslo: Høgskolen i Oslo og Akershus.

Bohlin, G., Hagekull, B. og Anderson, K. (2005). Behavioural inhibition as a precursor of peer social competence in early school age: The interplay with attachment and non-parental care. Journal of Developmental Psychology, 51(1), 1-19.

Bowlby, J. (1969). Attachment and loss: Vol. 1. Attachment. New York: Basic Books.

Braun,V. og Clarke,V. (2013). Successful qualitative research. A practical guide for beginners. Los Angeles: Sage.

Broberg, M. (2017). Betydelsen av inskoling och trygghet för de yngsta barnen i förskolan. Í I. Pramling-Samuelsson og A. Jonsson (ritstjórar), Förskolans yngsta barn - perspectiv på omsorg, lärande och lek (bls. 33-54). Stockholm: Liber AB.

Brooker, L. (2010). Constructing the triangle of care: Power and professionalism in practitioner / parent relationships. British Journal of Educational Studies, 58(2), 181-196. doi:10.1080/00071003752203

Chan, A. og Ritchie, J. (2016). Parents, participation, partnership: Problematising New Zealand early childhood education. Contemporary Issues in Early Childhood, 17(3), 289-303. doi:10.1177/1463949116660954

Clare, A. (2012). Creating a learning environment for babies and toddlers. Los Angeles: Sage.

Dahlberg, G. og Moss, P. (2005). Ethics and politics in early childhood education. London: Routledge Falmer.

Dalli, C. (2002). From home to childcare center: Challenges for mothers, teachers and children. Í A.-W. Dunlop og H. Fabien (ritstjórar), Transition in the early years: Debating continuity and progression for children in early education (bls. 38-51). London: Routledge.

Dalli, C., White, E. J., Rockel, J. og Duhn,. I. (2011). Quality early childhood education for under-two-year-olds: What should it look like? A literature review. Report for the Ministry of Education. Wellington: Ministry of Education, New Zealand.

Dockett, S. og Jóhanna Einarsdóttir. (2017). Continuity and change as children start school. Í N. Ballam, B. Perry og A. Garpelin (ritstjórar), Pedagogies of educational transitions. European and Antipodean research (bls. 133-150). Switzerland: Springer.

Drugli, M. B. og Undheim, A. M. (2011). Partnership between parents and caregivers of young children in full-time daycare. Child Care in Practice, 18(1), 51-65. doi:10.1080/13575279.2011.621887

Dunlop, A.-W. (2017). Transitions as a tool for change. Í N. Ballam, B. Perry og A. Garpelin (ritstjórar), Pedagogies of educational transitions. European and Antipodean research (bls. 257-273). Switzerland: Springer.

Educational Transitions and Change Research Group [ETC]. (2011). Transition to school. Position statement. Albury-Wodonga: Research Institute for Professional Practice, Learning and Education, Charles Sturt University.

Elfer, P. (2006). Exploring children's expressions of attachment in nursery. European Early Childhood Research Journal, 14(2), 81-95. doi: 10.1080/13502930285209931

Elfer, P. (2012). Emotion in nursery work: Work discussion as a model of critical professional reflection. Early Years: An International Research Journal, 32(2), 129-141. doi:10.1080/09575146.2012.697877

Hagstofa Íslands. (e.d.). Leikskólastig. Sótt af https://hagstofa.is/talnaefni/samfelag/menntun/leikskolastig/

Hanna Ragnarsdóttir. (2007). Börn og fjölskyldur í fjölmenningarlegu samfélagi og skólum. Í Hanna Ragnarsdóttir, Elsa Sigríður Jónsdóttir og Magnús Bernharðsson (ritstjórar), Fjölmenning á Íslandi (bls. 249-271). Reykjavík: Rannsóknarstofa í fjölmenningarfræðum KHÍ og Háskólaútgáfan.

Hanna Ragnarsdóttir. (2008). Collisions and continuities:Ten immigrant families and their children in Icelandic society and schools. Saarbrücken, Germany:VDM Verlag.

Hedlin, M. (2017). They only see their own child: An interview study of preschool teachers' perceptions about parents. Early Child Development and Care, 189(11), 85-95. doi:10.1080/03004430.2017.1412955

Hostettler Schärer, J. (2018). How educators define their role: Building 'professional' relationships with children and parents during transition to childcare: A case study. European Early Childhood Education Research Journal, 26(3), 1-12. doi: 10.1080/1350293X.2018.1442041

Hrönn Pálmadóttir. (2017). Gildi í samskiptum og leik ungra leikskólabarna. Sérrit Netlu 2017 - Innsýn í leikskólastarf. Sótt af http://netla.hi.is/serrit/2017/innsyn_leikskolastarf/003.pdf 
Johansen, B. (2009). Førskolelærere om barns oppholdstid i barnehagen. Nordisk Barnehageforskning, 2(3), 99-113.

Jóhanna Einarsdóttir. (2012). Raddir barna í rannsóknum. Í Jóhanna Einarsdóttir og Bryndís Garðarsdóttir (ritstjórar), Raddir barna (bls. 13-27). Reykjavík: Háskólaútgáfan.

Jón Torfi Jónasson. (2006). Frá gaeslu til skóla: Um próun leikskóla á Íslandi. Reykjavík: Rannsóknarstofa um menntakerfi og Félagsvísindastofnun Háskóla Íslands.

Kihlbom, M., Lidholt, B. og Niss, G. (2009). Förskola för de allra minsta på gott och ont. Stockholm: Carlsson.

Kristín Dýrfjörð. (2009). Dátttökuaðlögun - nýtt aðlögunarform í leikskóla. Rannsóknir í félagsvísindum X, Djóðarspegill, 681-690. Reykjavík: Félagsvísindastofnun Háskóla Íslands.

Kvale, S. og Brinkmann, S. (2009). Interviews. Learning the craft of qualitative research interviewing. Los Angeles: Sage.

Lichtman, M. (2013). Qualitative research in education. A user's guide. USA: Sage.

Litoselliti, L. (2003). Using focus groups in research. London: Continuum.

Lög um leikskóla nr. 90/2008. Sótt af https://www.althingi.is/lagas/nuna/2008090.html

Lög um breytingu á lögum um fæðingar- og foreldraorlof, nr. 95/2000 með síðari breytingum 2019. Sótt af https://www.althingi.is/altext/150/s/0829.html

Løkken, I. M., Bjørnestad, E., Broekhuizen, M. L. og Moser, T. (2018). The relationship between structural factors and interaction quality in Norwegian ECEC for toddlers. International Journal of Child Care and Education Policy 2(9), 3-15. doi: 10.1186/s40723-018-0048-z

Margetts, K. (2002). Planning transition programmes. Í H. Fabian og A.-W. Dunlop (ritstjórar), Transitions in the early years. Debating continuity and progression for children in early education (bls. 111-134). London: Routledge Falmer.

Margetts, K. (2014). Transition and adjustment to school. Í B. Perry, S. Dockett og A. Petriwskyj (ritstjórar), Transitions to school: International research, policy and practice (bls. 75-85). Dordrecht: Springer.

Mennta- og menningarmálaráđuneytið. (2011). Ađalnámskrá leikskóla. Reykjavík: Höfundur.

Mennta- og menningarmálaráðuneytið. (2015). Skýrsla starfshóps vegna pingsályktunar um leikskóla að loknu faðingarorlofi. Reykjavík: Höfundur.

NICHD Early Child Care Research Network. (2003). Does amount of time spent in child care predict socioemotional adjustment during the transition to kindergarten? Child Development, 74(4), 976-1005.

NICHD Early Child Care Research Network. (2006). Child-care effect sizes for the NICHD study of early child care and youth development. American Psychologist, 61(2), 99-116.

Nieto, S. og Bode, P. (2010). School reform and student learning: A multicultural perspective. Í J. A. Banks og C.A. M. Banks (ritstjórar), Multicultural education: Issues and perspectives (bls. 395-415). Hoboken: Wiley.

Nutbrown, C. (2011). Key concepts in early childhood education and care (2. útgáfa). Los Angeles: Sage.

Nutbrown, C. og Page, J. (2008). Working with babies and children from birth to three. London: Sage.

OECD. (2017). Starting strong V: Transitions from early childhood education and care to primary education. doi:10.1787/9789264276253-en

Reykjavíkurborg. (2010). Allir með en enginn eins. Fjölmenning í leikskóla. Aðlögun. Sótt af https://reykjavik. is/allir-med/adlogun

Reykjavíkurborg. (2011). Fjölskylda og leikskóli-Handbók um samstarf. Sótt af http://reykjavik.is/sites/default/ files/ymis_skjol/skjol_utgefid_efni/handbokumfore ldrasamstarf_0.pdf

Sigurður Kristinsson. (2013). Siðfræði rannsókna og siðanefndir. Í Sigríður Halldórsdóttir (ritstjóri), Handbók i aðferðafraeð rannsókna (bls. 71-88). Akureyri: Háskólinn á Akureyri.

Souto-Manning, M. (2013). Multicultural teaching in the early childhood classroom, approaches, strategies and tools, preschool-2nd grade. Washington DC:Teachers College Press.

Sæunn Kjartansdóttir. (2009). Árin sem enginn man. Reykjavík: Mál og menning.

Sylva, K., Melhuish, E., Sammons, P., Siraj-Blatchford, I. og Taggart, B. (2011). Preschool quality and educational outcomes at age 11: Low quality has little benefit. Journal of Early Childhood Research, 9(2), 109-124. doi: $10.1177 / 1476718 \times 10387900$ 
Traum, L. C. og Moran, M. J. (2016). Parents' and teachers' reflections on the process of daily transitions in an infant and toddler laboratory school. Journal of Early Childhood Teacher Education, 37(4), 331-350. doi: 10.1080/10901027.2016.1241967

Trewarthen, C. (2018). What young children give to our learning. Í C. Trewarthen, J. Delafield-Butt og A.W. Dunlop (ritstjórar), The child's curriculum. Working with the natural values of young children (bls. 13-38). Oxford: Oxford University Press.

Undheim, A. M. og Drugli, M. B. (2012). Experiences with full-time care attendance on young children in Norway: Parents' and early childhood teachers' views. International Research in Early Childhood Education, 3(1), 1-16. Sótt af http://kliniskpedagogikk.no/wp-content/uploads/2015/12/2012-Undheim-DrugliSliten-i-BH.pdf

Velferðarráðuneytið. (2016). Framtíðarstefna í faðingarorlofsmálum. Tillögur starfshóps. Sótt af www.stjornarradid.is/media/velferdarraduneyti-media/media/skyrslur2016/11032016_Framtidarstefna_i_daedingarorlofsmalum.pdf

Vuorinen, T., Sandberg, A., Sheridan, S. og Williams, P. (2014). Preschool teachers' views on competence in the context of home and preschool collaboration. Early Child Development and Care, 184(1), 149-159. do i.10.1080/03004430.2013.773992

White, E. J., Rutanen, N., Marwick, H., Souza Amorim, K., Karagiannidou, E. og Herold, L. K. M. (2020). Expectations and emotions concerning infant transitions to ECEC: International dialogues with parents and teachers. European Early Childhood Education Research Journal, 28(3). Sótt af https://www.tandfonline. com/doi/full/10.1080/1350293X.2020.1755495

Zachrisen, B. (2017). Kultursensitiv omsorg i barnehagen. Barn, (2-3), 105-119.

Hrönn Pálmadóttir (2020).

Viðhorf leikskólakennara og leiðbeinenda til upphafs leikskólagöngu.

Netla - Veftímarit um uppeldi og menntun. Menntavísindasvið Háskóla Íslands.

Sótt af http://netla.hi.is/greinar/2020/ryn/03

DOI: https://doi.org/10.24270/netla.2020.3 